cluded The Politics of Oil, Middle East Government and Politics, U.S. Foreign Policy, War and Peace, and Latin American Government and Politics. Certainly it would be possible to incorporate a women's studies dimension into those courses. My male colleagues may have had a blind spot in that regard-or maybe they thought the subject insignificant!

\section{References}

American Political Science Association. Module booklets in the APSA's Citizenship and Change: Women in American Politics (1988) (such as M.L. Shanley, Women's Rights, Feminism, and Politics in the United States). Washington: APSA

Gruberg, Martin M. 1968. Women in American Politics: An Assessment and Source Book. Oshkosh, WI: Academia.

\title{
Organizing A Course That Is Attentive to Issues of Racial and Sexual Difference
}

\author{
Helene Silverberg, University of California, Santa Barbara
}

"M ainstreaming" race and gender is the next intellectual frontier in building a curriculum that is enriching to us all. Of course, mainstreaming implicates many large issues of pedagogy - from the nature and uses of liberal education to the proper relationship between the classroom and the social context in which we teach and learn. But I shall confine my remarks here to some observations about the practical task of organizing a course that is attentive to issues of race and gender.

In my view, the conventional approach to mainstreaming - which could be described as "add women and/or Blacks and stir"'-raises more problems than it solves. My own early efforts to construct an inclusive syllabus ran into some troubling problems. I found, for example, that only the African American students read the assigned material about African Americans and only the women students read the assigned material about women. The White male students read only the material that did not include the words "race" and "sex" in the title. In effect, the "add and stir"' approach had the unfortunate effect of polarizing class discussion rather than educating everyone.

Moreover, the "add and stir" approach sends several wrong messages. It implies that studying race and gender means examining the political behavior and experience of women and African Americans. But by studying only subordinate groups, we obscure the ways in which dominant groups (i.e., Whites and men) are implicated in the unequal social relations of race and gender. It also assumes that issues of race and gender are present in politics only if women and/or African Americans are physically present in any given instance. This approach limits the topics into which race and gender can be sensibly integrated.

Most importantly, the "add and stir" approach conflates the key distinction between race and sex as biological characteristics (which, of course, they are) and race and gender as political categories, cultural constructions, and markers of inequality (which they need not be). This approach reflects the positivism and methodological individualism of much work in our discipline. And it has greatly misled us about the appropriate object of our study of race and gender.

I use two different approaches in organizing my syllabus and, perhaps more importantly, in teaching the material on the syllabus. First, I often employ gender as a theoretical lens in my discussion of different topics on my syllabus. During the discussion of the welfare state, for example, I challenge the conventional view that welfare states developed at the contested inter- section of (gender- and/or race-) neutral capitalism, democracy, and citizenship, and that they were built by labor unions, policy experts, state bureaucrats, and political elites. Drawing on recent research that uses gender as its analytical lens, I demonstrate that the conventional view is a partial view, that men and women following different policy agendas and political strategies built the welfare state, and that the appropriate relations between the sexes was as much at stake as the relations between the classes.

At other times, I focus on race and gender as collective identities and sources of social solidarity (rather than attributes of individuals) that are created in/through political processes and political institutions. During my discussion of political parties or policy making, for example, I challenge the notion that race and gender are static and unchanging political categories. Using recent work on the Great Society, I show how the racial targeting of many policies politicized racial identities among both Blacks and Whites. I also show how the new politicization of identities helped to reorganize American politics by fragmenting the Democratic party's biracial coalition and opening the way for a newly invigorated allWhite, cross-class Republican party.

These two approaches have several advantages. They emphasize 
that what is important is not racial and sexual differences per se but the difference those differences make. They place the focus of attention where it should be-on political processes and institutions, not groups of women and African Americans. Finally, they open up the curriculum in new ways. They enable me to include more material about women and Blacks in my courses (important for its own sake), but to do so as a vehicle for exploring political processes and institutions from a fresh perspective.

Admittedly, there is not yet a great deal of material available (especially on the undergraduate level) that facilitates the inclusion of race and gender in these ways. Articles and books by historians and historically oriented political scientists have worked best because their attention to change over time helps to emphasize that the meaning, place, and political significance of race and gender are socially constructed, highly fluid, and historically variable (not static attributes of skin color or reproductive organs).

\section{References}

MacKinnon, Catherine. 1987. Feminism Unmodified. Cambridge, MA: Harvard University Press.
Skocpol, Theda. 1991. Protecting Soldiers and Mothers. Cambridge, MA: Harvard University Press.

Weir, Margaret. 1992. Jobs and Politics. Princeton, NJ: Princeton University Press.

Woodward, C. Vann. 1955 (or any later edition). The Strange Career of Jim Crow. New York: Oxford University Press.

\section{About the Author \\ Helene Silverberg was assistant professor of politics at Princeton University at the time of her panel presentation. She is currently assistant professor of political science at the University of California, Santa Barbara.}

\section{Social Hierarchies as Systems of Power}

\section{Spike Peterson, University of Arizona}

My starting point, both inside and outside the classroom, is the assumption that social hierarchies such as race, physical ability, gender, class, age, and sexual preference constitute interlocking systems of power. Because these systems are empirically as well as conceptually linked, understanding any particular oppression requires analysis and action that takes seriously the connections among systems of power-even though these are not always complementary and sometimes contradict each other. Ability to see the connections depends on developing historical and cross-disciplinary contextual frameworks. The objective is to understand how we make (not dis-cover) our world(s) and how to remake (not reify) them in the light of critiques of domination.

In class, to show patterns of similarity and difference in domination practices, I list a number of "isms" across the chalkboard: anti-Semitism, racism, ageism, heterosexism, ableism, sexism, classism. I then ask students to identify the characteristic features of each system of domination. How is each subordinated group depicted in imagery, humor, stereotypes, linguistic and literary conventions, religious teachings, and by the press and on television? How do direct and indirect forms of power shape the group's experience spatially (e.g., residential segregation or restriction to the private sphere); temporally (e.g., historical variation in the group's oppression and different effects at different points in the life cycle); economically (e.g., discrimination in education, training, and employment, and unequal access to decision-making power and material resources); politically (e.g., unequal rights and exclusion from elite decision-making and formal political power); through violence or the threat of violence (e.g., police brutality, rape, battering, mugging, lynching, genocide)?

Patterns of similarity include how stereotypes, media depictions, and religious dogma reproduce negative stereotypes and "blaming the victim"; how apparently "harmless" jokes naturalize and trivialize domination by casting subordinated groups as inferior or suspiciously feminine; how economic impoverishment reproduces cycles of oppression; how forms of direct and structural violence back up all systems of unequal power.

Differences include the dismissal of the elderly and disabled as unproductive members of society; the exclusion of women and minorities from prestigious job categories and positions of intellectual, religious, and political authority; the issues of "passing" including discrimination against gays/lesbians only if they are "out"; differences in the use and threat of violence including rape and battering of women that is personal-by those they know/ love-but also impersonal-in public and as a component of militarism and commercialized sex; enslavement and lynching of Blacks in the past, and police brutality in the present; state-based genocidal elimination of Jews and indigenous peoples; and the presence of both targeted and impersonal gay bashing and murder.

Societal consciousness of and responses to oppression also reveal patterns. Most people consider racism more oppressive than sexism, in part because we deny the systemic violence that women suffer, and we are relatively more conscious of the economic immisera- 